\title{
Experimental Study on Diflubenzuron: Degradation in Freshwater and Bioconcentration in Mosquitofish Following Chronic Exposure
}

\author{
Nedjoua Zaidi ${ }^{1}$, Jean-Pierre Farine ${ }^{2}$, Noureddine Soltani ${ }^{{ }^{*}}$ \\ ${ }^{1}$ Laboratory of Applied Animal Biology, Department of Biology, Faculty of Sciences, Badji Mokhtar University of Annaba, Annaba, \\ Algeria; ${ }^{2}$ Centre des Sciences du Goût et de l'Alimentation, Centre National de la Recherche Scientifique-Unité Mixte de Recherche, \\ Faculté des Sciences, Université de Bourgogne, Dijon, France. \\ Email: *noureddine.soltani@univ-annaba.org
}

Received November $17^{\text {th }}, 2012$; revised December $15^{\text {th }}, 2012$; accepted January $10^{\text {th }}, 2013$

\begin{abstract}
Diflubenzuron (DFB, trade name dimilin ${ }^{\circledR} 25 \mathrm{WP}$ ) is a chitin synthesis inhibitor widely used against forest insect pests in Algeria. Prior to implementation of these products as chemical agents for mosquito control, knowledge on their potential effects on non-target organisms and its behaviour in water are needed. Therefore, the present study was focused on DFB and aimed to use an HPLC procedure developed previously in order to obtain information on its degradation in freshwater and its bioconcentration in adult females of the fish Gambusia affinis (Cyprinodondiformes, Poeciliidae), which is one of the best candidates for biological control programs against mosquitoes. The adult females were exposed to dimilin ${ }^{\circledR}$ (initial concentration $312 \mathrm{ng}$ a.i. $/ \mathrm{ml}$ ) for 28 days and residues analysis determined at different exposure times $(0,7,14,21$ and 28 days). The concentration of DFB in freshwater decreased with exposure time while the amount of residues detected at the surface of the fish body increased progressively to reach a maximum at day 14 (162.7 $\pm 14.0 \mathrm{ng}$ /fish) and declined thereafter during the exposure period. In addition, DFB incorporation into body increased with decreasing DFB concentration in water at each exposure time. The following average distribution was noted at the end of experiment ( 28 days): about $33 \%$ of the applied concentration was detected on the surface of fish body and was recovered by simple rinsing, and about $67 \%$ was found inside the fish body. A degradation in water and surface of fish occurred starting day 14 during the experimental period. Thus, about $40 \%$ of the initial concentration was degraded in freshwater after 28 days. The results are discussed to develop a better understanding of the degradation of dimilin in water and their potential effect on non-target organisms for its application for controlling mosquito.
\end{abstract}

Keywords: Diflubenzuron; Dimilin; Gambusia Affinis; Residues; HPLC; Degradation; Bioconcentration

\section{Introduction}

Mosquitoes are the most important vectors of pathogens causing human and animal diseases [1]. Culex pipiens L. (Diptera, Culicidae), one of the most investigated organisms in Europe [2] and Algeria [3,4]. It is generally controlled by organophosphate, carbamate and/or pyrethroid insecticides [5,6]. However, the intensive use of conventional insecticides causes secondary effects on the environment [7] and alternative methods are needed [8]. In this context, the search for new insect-selective insecticides with minimal ecotoxicological risks is relevant. Insect growth regulators (IGRs) seem promising because of their specific mode of action on insects and their lower toxicity against non-target organisms than conventional insecticides $[9,10]$. Among IGRs, chitin synthesis in-

${ }^{*}$ Corresponding author. hibitors as diflubenzuron (DFB) and flucycloxuron (FCX) are widely used against pest insects in forestry, particularly in Algeria. DFB is more potent than, FCX for mosquito control $[11,12]$. Prior to implementation of these products as chemical agents for mosquito control in natural conditions, knowledge on their behaviour in water and on their potential effects on non-target organisms are needed. Above all, it appears important to examine the IGR effects on the fish Gambusia affinis (Cyprinodondiformes, Poeciliidae), which is one of the best candidates for biological control programs against mosquitoes in the world $[13,14]$ and seems more efficient than two autochthonous Cyprinidae species, Pseudophoxinus callensis (Guichenot, 1850) and P. guichenoti (Pellegrin, 1920) [15]. Recent results have suggested that FCX and, to a lesser extent, DFB, exhibit low toxic effects on this non-target fish species [16]. Several procedures have 
been developed for the analysis of DFB or related compounds using high-performance liquid chromatography (HPLC) [17-22].

Thereafter, this procedure was routinely applied for evaluation of DFB residues in different organs and tissues from several insect pests [23-25], and also to study DFB degradation in seawater [26]. These toxicity and degradation studies were limited almost exclusively to acute exposure of DFB. Therefore, the present study was focused on DFB and aimed to use HPLC in order to obtain information on its degradation in freshwater and its bioconcentration by adult females of this larvivorous fish, G. affinis in long-term tests (28-day) under laboratory conditions. These data will permit us to evaluate the possible field application of this potent insecticide for controlling mosquito pullulations in an integrated manner.

\section{Materials and Methods}

\subsection{Animal Test}

Gambusia affinis (Baired and Girard, 1845) were collected from Kherraza River $\left(4^{\circ} 04^{\prime} \mathrm{N}, 04^{\circ} 02^{\prime} \mathrm{E}\right)$ as previously described [27] and acclimatized for at least 15 days before DFB exposure. Experiments were run in 50-liter glass aquaria $(60 \times 30 \times 30 \mathrm{~cm})$ under continuous aerated dechlorinated water. Fish were fed daily using commercial food (Tetramin ${ }^{\circledR}$, Germany). The natural photoperiod of 14:10 (L:D) was maintained. Exposed and control adult females (body weight $0.425 \pm 0.048 \mathrm{~g}$; length 3.54 $\pm 0.32 \mathrm{~cm}$ ) were placed in aquaria (30 fishes per aquarium) under laboratory conditions: temperature $21.03^{\circ} \mathrm{C} \pm$ $0.31^{\circ} \mathrm{C}$; salinity $242.00 \pm 33.57 \mathrm{mg} / \mathrm{L} ; \mathrm{pH} 8.07 \pm 0.09$; dissolved oxygen $2.88 \pm 0.12 \mathrm{mg} / \mathrm{L}$.

\subsection{Insecticide and Treatement}

Dimilin $^{\circledR}$ (wettable powder $25 \%$ active ingredient, a.i.), the trade name of diflubenzuron, and technical grade diflubenzuron $(97.9 \%$ purity used as standard for quantification of residues) were kindly provided by $\operatorname{Pr}$. G. Smagghe (Ghent University, Belgium). Dimilin was added to the rearing water at a final concentration of 312 ng a.i./mL. This concentration was chosen according to concentrations tested on several fish species [28-31]. Fish starved for 2 days were exposed to the insecticide for 28 days. Untreated fishes were also used as controls (For each series, three aquaria were used, each containing 30 fishes).

\subsection{Residue Extraction}

DFB residues in freshwater and in fishes (surface and tissues) were performed using high performance liquid chromatography (HPLC) procedure as described previously [26]. At different exposure times $(0,7,14,21$ and
28 days), $3 \mathrm{~mL}$ of rearing water and 3 females were randomly sampled from control and treated series (1 female per aquarium) and analysed individually as follows. Each female was rinsed using $3 \mathrm{~mL}$ of acetonitrile-water (50 50 by volume), then eviscerated and weighed. The remaining tissues were homogenised in $3 \mathrm{~mL}$ of acetonitrile-water (50 - 50) using a Sonifier cell disrupter B-30 (Branson Ultrasons, France). After centrifugation (5000 $\mathrm{g}$ for $10 \mathrm{~min}$ ) and evaporation of supernatant in Speed Vac (Varian), the various extracts from freshwater, surface and tissues of fishes were stored at $-10^{\circ} \mathrm{C}$ until analysis.

\subsection{High Performance Liquid Chromatography Analysis}

Each extract was dissolved in $200 \mu \mathrm{L}$ of acetonitrilewater $(50-50)$ and small aliquots $(10-20 \mu \mathrm{L})$ were twice injected into a Waters HPLC (600 E) equipped with two pumps (M6000 A), a detector (Waters 996 operated at $254 \mathrm{~nm}$ ), an automatic injector (WISP $710 \mathrm{~B}$ ) and a M 740 system Controller Data module. A $125 \mathrm{~mm} \times 4 \mathrm{~mm}$ i.d. Merck RP18 column ( $7 \mu \mathrm{m}$ particles) was used with acetonitrile-water (50 - 50 by volume) as the mobile phase at a flow rate of $1 \mathrm{~mL} / \mathrm{min}$. Chromatography was performed at room temperature (about $25^{\circ} \mathrm{C}$ ). A calibretion curve was established with technical grade diflubenzuron (99.7\% purity) using a Nec Power Mate 433 computer equipped with Waters Millenium Software.

\subsection{Bionconcentration Factor Determination}

Bioconcentration was estimated by using the bioconcentration factor (BCF) defined according to [32] as the residue concentration in the fish tissues divided by that in the water (both in $\mathrm{ng} / \mathrm{mL}$ ). It was calculated for the different exposure times $(0,7,14,21$ and 28 days).

\subsection{Statistics}

The normality of data was verified using the Kolmogorov-Smirnov test, and the homogeneity of variances was checked by Levene's test. Data have been expressed by the mean \pm standard deviation $(\mathrm{m} \pm \mathrm{SD})$. Data were subjected to analysis of variance (ANOVA) followed by Tukey's test. All statistical analyses were performed using MINITAB Software (Version 14, Penn State College, PA, USA) and $p<0.05$ was considered to be a statistically significant difference. The number of fishes and repeats used are given with the results.

\section{Results}

\subsection{Determination of Residue in Freshwater}

According to previous data, the response of the UV de- 
tector was linear from $2 \mathrm{ng}$ to $1000 \mathrm{ng}$ of DFB [22]. Under over experimental conditions, the retention time of DFB was about 8.30 min (Figure 1(a)). DFB was detected in extracts recovered from rearing water (Figure 1(b)), rinsing water (Figure 1(c)) and body of treated fish (Figure 1(d)). The results of residues analysis in rearing freshwater, surface and inside fish body are summarized in Tables 1-3. DFB was not detected in control water. The concentration of DFB in water decreased with exposure time and our data show that $60 \%$ of initial DFB was still present after 28 days exposure (Table 1).

\subsection{Determination of Residue in Fish}

The amount of DFB residues detected on surface of the fish body increase progressively to reach a maximum within 14 day exposure $(162.7 \pm 14.0 \mathrm{ng} /$ animal $)$ and declined thereafter during the exposure period (Table 2). In addition, the increase of body DFB incorporation was mirrored by a simultaneous decrease of DFB concentration in water with increasing exposure times. This body accumulation ranged from $54.2 \pm 4.5 \mathrm{ng} /$ fish after 7 days of exposure to $160.0 \pm 11.3 \mathrm{ng} /$ fish at the end of experiment (Table 2).

This increase was rather low, and it is only after 21 days of exposure that this amount became higher than that found on the fish skin.

At the end of experiment (28 days), the following average distribution was noted: about $33 \%$ of the applied concentration was detected on the surface of fish body and was recovered by simple rinsing, and about $67 \%$ was found inside the fish body. In our study, there was a progressive incorporation into fish body and a degradation in water and surface of fish occurred starting day 14 during the experimental period. Thus only about $40 \%$ of the initial dose was degraded in water after 28 days. In addition, under the laboratory conditions the half-life of DFB in freshwater determined from the regression curve showing the degradation as function the time $(\mathrm{Y}=-2.72$ $\left.+1.52 \mathrm{X} ; \mathrm{R}^{2}=0.979\right)$ was 34.71 days. The bioconcentration factor (BCF) (Table 3) calculated as DFB concentration in the organism divided by the DFB concentration in the water vary from $0.462 \pm 0.089$ (minimum value at day 7) to $3.115 \pm 0.710$ (maximum value at day 28).

\section{Discussion}

G. affinis remains one of the best candidates for biological control programs against mosquitoes $[13,14]$. This fish has been the subject of several studies including be-

Table 1. Concentrations (ng/mL) of dimilin residue detected by HPLC in freshwater and degradation as function the exposure time $(m \pm s ; n=3)$.

\begin{tabular}{ccc}
\hline $\begin{array}{c}\text { Exposure time } \\
\text { (days) }\end{array}$ & $\begin{array}{c}\text { Concentration } \\
\text { (ng/mL) }\end{array}$ & Degradation (\%) \\
\hline 0 & $312.0 \pm 0.0$ & $0.0 \pm 0.0$ \\
7 & $297.2 \pm 9.2$ & $4.8 \pm 1.14$ \\
14 & $259.8 \pm 11.2$ & $16.8 \pm 0.72$ \\
21 & $215.0 \pm 8.7$ & $31.1 \pm 1.25$ \\
28 & $187.2 \pm 8.6$ & $40.0 \pm 1.83$ \\
\hline
\end{tabular}

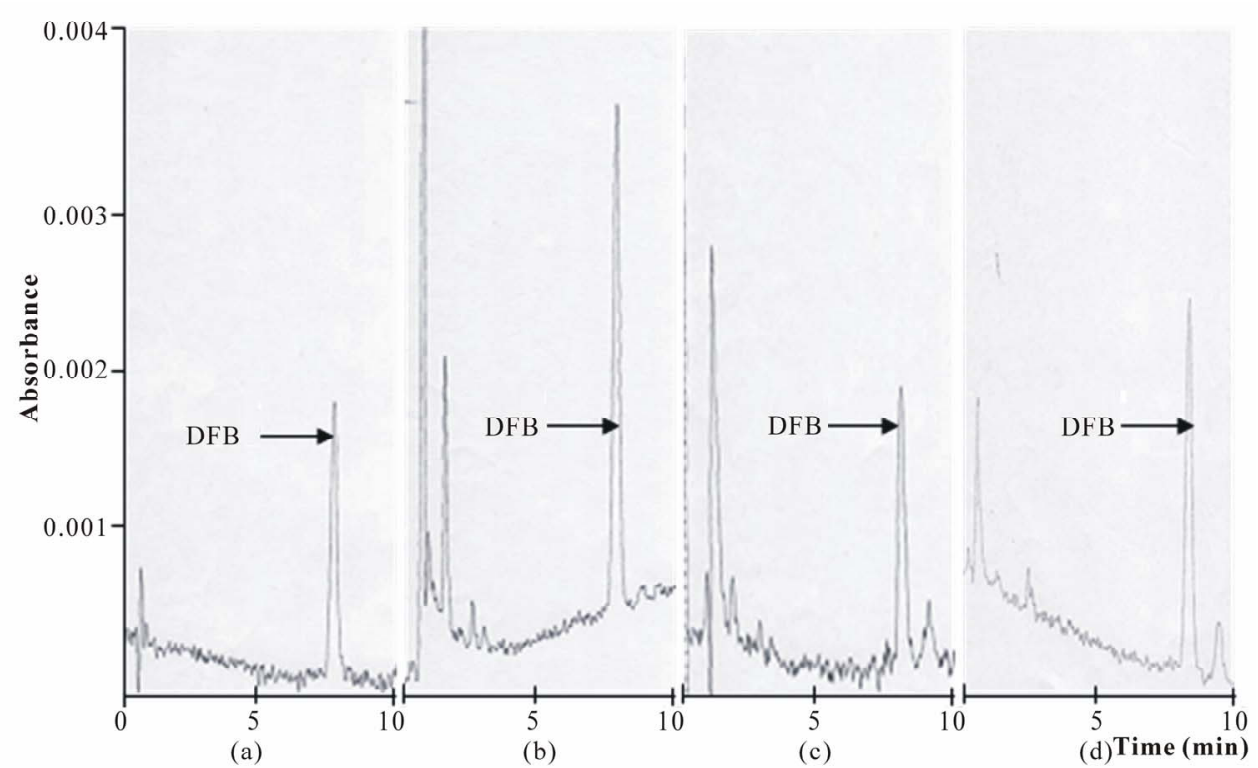

Figure 1. High performance liquid chromatographs from: (a) $10 \mathrm{ng}$ of standard (DFB); (b) Extract from the rearing water $(20 \mu \mathrm{L})$; (c) Extract from rinsing water $(20 \mu \mathrm{L})$; (d) Extract from the fish body $(20 \mu \mathrm{L})$ after 28 days of exposure. 
Table 2. Amounts (ng/fish) of dimilin residue detected by HPLC and its distribution (\% of initial concentration) on the surface and inside the body of Gambusia affinis as a function of exposure time $(\mathrm{m} \pm \mathrm{s} ; \mathrm{n}=3)$.

\begin{tabular}{cccccc}
\hline $\begin{array}{c}\text { Exposure time } \\
\text { (days) }\end{array}$ & $\begin{array}{c}\text { Amount on surface } \\
\text { (ng/fish) }\end{array}$ & $\begin{array}{c}\text { Amount in body } \\
\text { (ng/fish) }\end{array}$ & $\begin{array}{c}\text { Level on surface } \\
\text { (\%) }\end{array}$ & $\begin{array}{c}\text { Level in body } \\
\text { (\%) }\end{array}$ & $\begin{array}{c}\text { Total quantity } \\
\text { (ng/fish) }\end{array}$ \\
\hline 0 & $0.0 \pm 0.0$ & $0.0 \pm 0.0$ & 0 & 0 & $0.0 \pm 0.0$ \\
7 & $156.0 \pm 45.1$ & $54.2 \pm 4.5$ & 74 & 26 & $210.2 \pm 45.1$ \\
14 & $162.7 \pm 14.0$ & $101.5 \pm 3.3$ & 62 & 38 & $264.1 \pm 12.9$ \\
21 & $120.0 \pm 22.6$ & $132.6 \pm 14.3$ & 48 & 52 & $252.0 \pm 15.2$ \\
28 & $78.7 \pm 8.3$ & $160.0 \pm 11.3$ & 33 & 67 & $238.6 \pm 15.6$ \\
\hline
\end{tabular}

Table 3. Bioconcentration factor (BCF) of diflubenzuron in a freshwater fish Gambusia affinis as function the exposure time ( $m \pm s ; n=3)$.

\begin{tabular}{ccc}
\hline $\begin{array}{c}\text { Exposure time } \\
\text { (days) }\end{array}$ & $\begin{array}{c}\text { Tissue concentration } \\
\text { (ng/g) }\end{array}$ & BCF \\
\hline 0 & - & - \\
7 & $137 \pm 30$ & $0.462 \pm 0.089$ \\
14 & $221 \pm 30$ & $0.850 \pm 0.087$ \\
21 & $430 \pm 38$ & $2.007 \pm 0.261$ \\
28 & $586 \pm 157$ & $3.115 \pm 0.710$ \\
\hline
\end{tabular}

havioural ecology, histopathology, reproductive biology, endocrinology and toxicology [33-35].

The normal development of the ovaries has already been described $[27,36]$ and the obtained data provide an experimental basis to study the activity of IGRs on females.

Several workers have already reported on the interactions of DFB with various components of the environ ment. Laboratory and field studies show that DFB can have adverse impacts on aquatic organism [29,37-39]. Both the tested IGR [12] and the mosquitofish [15] are useful for the regulation of mosquitoes. Although DFB has low water solubility, water may represent a significant route through which non-target organisms can be exposed to DFB or its degradation products, particularly if DFB is used as a mosquito larvicide. The fate and persistence of DFB in pond and lake environment has been a subject of interest of some years [40-42].

Most methods use liquid chromatography with UV detection for the analysis of benzylphenylurea compounds such as DFB $[43,44]$. HPLC was found to be one of the best methods due to its sensitivity [17]. Dimilin is degraded in the environment mainly by photodegradation and hydrolysis [40], producing as major metabolites: 2,6diflurobenzamide, 4-chlorophenylurea, 4-chloroacetanilide, 4-chloroaniline and N-methyl-4-chloroaniline [45]. Among them, 4-chloroaniline shows a higher toxicity to fish than the original product [46].
In the present study, the rapid extraction procedure and the analysis by a sensitive HPLC method [22] allowed the determination of individual residue levels. Quantitative analysis of DFB in rearing water and surface of fish by HPLC indicate that there was a significant reduction in DFB concentration. This reduction is essentially due to degradation and in a lesser level to uptake of DFB into the fish. Similarly, HPLC analysis of DFB residues in seawater samples showed a degradation of $40 \%$ from the initial concentration $(0.01 \mu \mathrm{g} / \mathrm{mL})$ after 14 days [26]. In addition, under our laboratory conditions, the half-life of DFB determined in the current study in freshwater is higher than 4 weeks. Several factors such as $\mathrm{pH}$, salinity and water temperature may affect the toxicity and persistence of DFB. Dilute solutions of DFB were not stable in field waters and that in tap waters stability was least when both $\mathrm{pH}$ and water temperature were relatively high [18]. Previous studies show that DFB normally persists for only about 2 to 3 days $[18,47,48]$. Low concentrations can persist for 7 weeks or longer in pond waters under low $\mathrm{pH}$ and temperatures [49]. Thus, a half-time of 3 days at $\mathrm{pH}=10$ in freshwater was reported [46] against a half-life of 1.5 to 2 weeks at $\mathrm{pH}$ between 8 - 8.5 [50].

The amounts of DFB detected inside G. affinis indicate that there was a progressive accumulation into the fish body. The rate of DFB uptake increased with the DFB concentration in the freshwater. In the present study, the bioconcentration factor $(\mathrm{BCF})$ ranged from $0.462 \pm 0.089$ (minimum value at day 7) to $3.115 \pm 0.710$ (maximum value at day 28), indicating that DFB has a potential to bioconcentrate in this fish starting day 21 of exposure period. Similarly, analysis of DFB in Oreochromis niloticus exposed to $100 \mu \mathrm{g} / \mathrm{mL}$ indicated a bioconcentration ratio of 29.8 fold after $48 \mathrm{~h}$ [42]. In addition, the $\mathrm{BCF}$ of DFB in different fish species was determined. Thus, DFB is accumulated from water into fish tissues at levels up to 80 fold within $24 \mathrm{~h}$ when fish are exposed to concentrations of $10 \mathrm{ng} / \mathrm{mL}$ [32]. In another study, $O$. niloticus exposed for 21 days to DFB at 2.5 and $5 \mu \mathrm{g} / \mathrm{mL}$ accumulated DFB 76 and 99 times greater than the water concentration, respectively [30]. 
In conclusion, an HPLC method for determination of dimilin commercial formulation in freshwater and fish body was used. At the end of the exposure period (28 days), $60 \%$ of the compound was still detected in rearing water. According to our previous study, the compound appears more stable in freshwater than in seawater. Thus, dimilin can be used for controlling of mosquitoes in an integrated manner according to its relative stability in freshwater and its slight toxicity against this non-target fish species as reported previously. In order to complete the present finding, a further study is needed to determine the major metabolites of DFB resulting from its degradation under our experimental conditions.

\section{Acknowledgements}

The authors wish to thank Pr. G. Smagghe (Ghent University) for donating insecticides. This study was financed by the Algerian Fund for Scientific Research and by the Ministry of High Education and Scientific Research of Algeria (CNEPRU and PNR projects to Pr. N. Soltani).

\section{REFERENCES}

[1] P. E. Kaufman, R. S. Mann and J. F. Butler, "Insecticidal Potency of Novel Compounds on Multiple Insect Species of Medical and Veterinary Importance," Pest Management Science, Vol. 67, No. 1, 2011, pp. 26-35. doi:10.1002/ps.2025

[2] L. Toma, M. Menegon, R. Romi, E. De Matthaeis, M. Montanaria and C. Severini, "Status of Insecticide Resistance in Culex pipiens Field Populations from NorthEastern Areas of Italy Before the Withdrawal of OP Compounds," Pest Management Science, Vol. 67, No. 1, 2011, pp. 100-106. doi:10.1002/ps.2039

[3] N. Rehimi and N. Soltani, "Laboratory Evaluation of Alsystine. A Chitin Synthesis Inhibitor, against Culex pipiens L. (Diptera Culicidae): Effects on Development and Cuticle Secretion," Journal of Applied Entomology, Vol. 123, No. 7, 1999, pp. 437-441. doi:10.1046/j.1439-0418.1999.00388.x

[4] N. Rehimi and N. Soltani, "Laboratory Evaluation of Andalin, an Insect Growth Regulator Interfering With Cuticle Deposition, Against Mosquito Larvae," Revue Scientifique \& Technique, Vol. 18, 2002, pp. 106-108.

[5] F. Tine-Djebar and N. Soltani, “Activité Biologique D'un Agoniste Non Stéroïdien de L'hormone de Mue sur Culiseta longiareolata: Analyses Morphométrique, Biochimique et Energétique," Synthèse, Vol. 18, 2008, pp. 23-34.

[6] F. Tine-Djebbar, A. B. Larhem and N. Soltani, "Enzyme Immunoassay Measurements of the Molting Hormone in Different Post-Embryonic Stages of Two Mosquito Species, Culex pipiens and Culiseta longiareolata," African Journal of Biotechnology, Vol. 10, No. 67, 2011, pp. 15195-15199. doi:10.5897/AJB11.2085
[7] M. G. Paoletti and D. Pimentel, "Environmental Risks of Pesticides versus Genetic Engineering for Agricultural Pest Control," Journal of Agricultural and Environmental Ethics, Vol. 12, No. 3, 2000, pp. 279-303. doi:10.1023/A:1009571131089

[8] S. D. Frank, "Biological Control of Arthropod Pests Using Banker Plant Systems: Past Progress and Future Directions," Biological Control, Vol. 52, 2010, pp. 8-16. doi:10.1016/j.biocontrol.2009.09.011

[9] T. S. Dhadialla, A. Retnakaran and G. Smagghe, "Insect Growth and Development Disrupting Insecticides," In: L. I. Gilbert, I. Kostas and S. Gill, Eds., Comprehensive Insect Molecular Science, Pergamon Press, New York, 2005, pp. 55-116. doi:10.1016/B0-44-451924-6/00076-4

[10] T. S. Dhadialla and R. Ross, "Bisacylhydrazines: Novel Chemistry for Insect Control," In: W. Kramer and U. Schimer, Eds., Modern Crop Protection Compounds, Wiley-VCH, Weinheim, 2007, pp. 773-796.

[11] N. Soltani and N. Rehimi, "Laboratory Evaluation of Andalin, a New Insecticide Interfering with Cuticle Deposition, against Culex pipiens," Journal Algérien de Medecine, Vol. 11, 2001, pp. 28-33.

[12] N. Rehimi, "Etude de La Reproduction Chez Culex pipiens pipiens. Aspects: Morphologique, Ethologique et Physiologique. Effets de Quelques Inhibiteurs du Développement sur Quelques Paramètres Biologiques," Ph.D. Thesis, Annaba University, Algeria, 2004.

[13] R. Kumar and J. S. Hwang, "Larvicidal Efficiency of Aquatic Predators: A Perspective for Mosquito Control," Zoological Studies, Vol. 45, No. 4, 2006, pp. 447-466.

[14] W. E. Walton, "Larvivorous Fish Including Gambusia," In: T. Floore, Ed., Biorational Control of Mosquitoes, Journal of the American Mosquito Control Association, Vol. 23, No. 2, 2007, pp. 184-220.

[15] F. Bendali, F. Djebbar and N. Soltani, "Efficacité Comparée de Quelques Espèces de Poisons a L'égard de Divers Stades de Culex pipiens L. Dans des Conditions de Laboratoire," Parasitica, Vol. 57, No. 4, 2001, pp. 255 265.

[16] N. Zaidi and N. Soltani, "Environmental Risks of Two Chitin Synthesis Inhibitors on Gambusia affinis: Chronic Effects on Growth and Recovery of Biological Responses," Biological Control, Vol. 59, 2011, pp. 106-113. doi:10.1016/j.biocontrol.2011.04.001

[17] C. Corley, R. Miller and K. Hill, "Determination of $\mathrm{N}$-(4-Chlorophenyl)-N-(2,6-difluorobenzoyl)-urea in Milk Of High-Speed Liquid Chromatography," Journal of the Association of Official Analytical Chemists, Vol. 57, 1974, pp. 1269-1271.

[18] C. H. Schaefer and E. F. Dupras, "Factors Affecting the Stability of Dimilin in Water and The Persistence of Dimilin in Field Waters," Journal of Agricultural and Food Chemistry, Vol. 24, No. 4, 1976, pp. 733-739. doi:10.1021/jf60206a013

[19] G. E. Spates and J. E. Wright, "Residues of Diflubenzuron Applied Topically to Adult Stable Flies," Journal of Economic Entomology, Vol. 73, 1980, pp. 595-598.

[20] A. H. Abdel Monem and R. O. Mumma, "Development 
of an Analytical Procedure for an Insect Growth Regulator (EL-494) Employing High-Pressure Liquid Chromatography and Its Application on Residues," Journal of Agricultural and Food Chemistry, Vol. 29, No. 1, 1981, pp. 75-78. doi:10.1021/jf00103a020

[21] A. I. Valenzuela, Y. Pico and G. Font, "Liquid Chromatography/Atmospheric Pressure Chemical IonizationMass Spectrometric Analysis of Benzoylurea Insecticides in Citrus Fruits," Rapid Communications in Mass Spectrometry, Vol. 14, No. 7, 2000, pp. 572-577.

doi:10.1002/(SICI)1097-0231(20000415)14:7<572::AIDRCM911>3.0.CO;2-2

[22] N. Soltani, J. P. Delbecque and J. Delachambre, "Penetration and Insecticidal Activity of Diflubenzuron in Tenebrio molitor Pupae," Pesticide Science, Vol. 14, No. 6, 1983, pp. 615-622. doi:10.1002/ps.2780140609

[23] N. Soltani and N. Soltani-Mazouni, "Diflubenzuron and Oogenesis in the Codling Moth, Cydia pomonella (L.)," Pesticide Science, Vol. 34, No. 3, 1992, pp. 257-261. doi:10.1002/ps.2780340311

[24] N. Soltani, N. Pitoizet, N. Soltani-Mazouni and J. Delbecque, "Quantification par Chromatographie Liquide à Haute Perfermance du Diflubenzuron et du Flucyloxuron chez Tenebrio molitor et Thaumetopoea pytiocampa," Proceedings of International Symposium on Crop Protection, Vol. 59, No. 2, 1994, pp. 481-486.

[25] M. E. H. Khebbeb, J. Delachambre and N. Soltani, "Ingested Diflubenzuron Disturbed the Lipidic Metabolism during the Sexual Maturation of Mealworms," Pesticide Biochemistry and Physiology, Vol. 58, No. 3, 1997, pp. 209-217. doi:10.1006/pest.1997.2296

[26] N. Soltani and S. M. Morsli, "Quantification du Dimilin par Chromatographie Liquide à Haute Performance: Etude de sa Dégradation dans L'eau de Mer," Journal de Recherche Océanographique, Vol. 28, 2003, pp. 118-120.

[27] H. Drardja-Beldi, “Contribution à l'Etude de Gambusia affinis (Téléostéen, Poeciliidae), Poisson Prédateur des Larves de Moustiques, Croissance des Alevins, Etude du Cycle Sexuel et Corrélations Métapoliques," Ph.D. Thesis, Annaba University, Algeria, 1993.

[28] D. J. MadderJ and W. L. Lockhart, “A Preliminary Study of the Effects of Diflubenzuron and Methoprene on Rainbow Trout (Salmo gairdneri Richardson)," Bulletin of Environmental Contamination and Toxicology, Vol. 20, No. 1, 1978, pp. 66-70. doi:10.1007/BF01683487

[29] E. G. Ellgaard, J. T. Barber, S. C. Tiwari and A. L. Friend, "An Analysis of the Swimming Behavior of Fish Exposed to the Insect Growth Regulators, Methoprene and Diflubenzuron," Mosquito News, Vol. 39, No. 2, 1979, pp. 311-314.

[30] M. T. Ahmed and A. H. Eid, "Accumulation of Diflubenzuron in Bolti Fish Orechromis niloticus," Nahrung, Vol. 35, No. 1, 1991, pp. 27-31. doi:10.1002/food.19910350107

[31] L. P. Maduenho and B. R. Martinez, "Acute Effects of Diflubenzuron on the Freshwater Fish Prochilodus lineatus," Comparative Biochemistry and Physiology, Vol. 148, 2008, pp. 265-272.
[32] C. H. Schaefer, E. F. Dupras, R. J. Stewart, L. W. Davidson and A. E. Colwell, "The Accumulation and Elimination of Diflubenzuron by Fish," Bulletin of Environmental Contamination and Toxicology, Vol. 21, No. 1-2, 1979, pp. 249-254.

[33] Y. Koya, A. Fujita, F. Niki, E. Ishihara and H. Miyama, "Sex Differentiation and Pubertal Development of Gonads in the Viviparous Mosquitofish, Gambusia affinis," Zoological Science, Vol. 20, No. 10, 2003, pp. 1231-1242. doi:10.2108/zsj.20.1231

[34] J. Venkateswara Rao, G. Begum, R. Pallela, P. K. Usman and R. Nagaswara Rao, "Changes in Behavior and Brain Acetylcholiesterase Activity in Mosquitofish Gambusia affinis in Response to the Sub-Lethal Exposure to Chloropyrifos," International Journal of Environmental Research and Public Health, Vol. 2, No. 3, 2005, pp. 478483. doi:10.3390/ijerph2005030013

[35] C. C. Smith and R. C. Sargent, "Female Fitness Declines with Increasing Female Density but Not Mele Harassment in the Western Mosquitofish, Gambusia affinis," Animal Behaviour, Vol. 71, 2006, pp. 401-407. doi:10.1016/j.anbehav.2005.06.003

[36] H. Drardja-Beldi, "Etude de Gambusia affinis (Poisson, Téléostéen) et Donax trunculus (Mollusque, Pélécypode): Ecologie, Physiologie et Impacts de Quelques Altéragènes," Ph.D. Thesis, Annaba University, Algeria, 2007.

[37] H. Drardja-Beldi and N. Soltani, "Laboratory Evaluation of Dimilin on Growth and Glutathione Activity in Mosquitofish, A Non Target Species," Communications in Agricultural and Applied Biological Sciences, Vol. 68, No. 4, 2003, pp. 299-305.

[38] S. M. Morsli and N. Soltani, "Effets d'Un Insecticide Inhibiteur de la Synthèse de la Chitine, le Diflu- benzuron, sur la Cuticule de la Crevette Penaeus kerathurus," Journal de Recherche Océanographique, Vol. 28, 2003, pp. 85-88.

[39] N. Soltani, H. Lachekhab and G. Smagghe, "Impact of the Insect Growth Regulator Diflubenzuron on Biochimical Composition of Cuticle of The Shrimp Penaeus kerathurus," Communications in Agricultural and Applied Biological Sciences, Vol. 74, No. 1, 2009, pp. 137-141.

[40] K. M. S. Sundaram, S. B. Holmes, D. P. Kreutzweiser, A. Sundaram and P. D. Kingsbury, "Environmental Persistence and Impact of Diflubenzuron in a Forest Aquatic Environment Following Aerial Application," Archives of Environmental Contamination and Toxicology, Vol. 20, No. 3, 1991, pp. 313-324. doi:10.1007/BF01064396

[41] A. Selvik, P. K. Hansen, A. Ervik and O. B. Samuelsen, "The Stability and Persistence of Diflubenzuron in Marine Sediments Studied Under Laboratory Conditions and the Dispersion to the Sediment Under a Fish Farm Following Medication," Science of the Total Environment, Vol. 285, No. 1-3, 2002, pp. 237-245.

[42] L. S. Ricardo, J. M. C. Paulo and M. V. Eny, "Analysis of Diflubenzuron in Tilapia Filet by HPLC-DAD," Journal of Chromatographic Science, Vol. 47, 2009, pp. 785-788.

[43] D. J. Austin and K. J. Hall, "A Method of Analysis for the Determination of Binapacryl, Bupirimate and Difluben- 
zuron on Apple Foliage and Fruit, and Its Application to Persistence Studies," Pesticide Science, Vol. 12, No. 5, 1981, pp. 495-502. doi:10.1002/ps.2780120505

[44] K. A. Barnes, J. R. Startin, S. A. Thorpe, S. L. Reynolds and R. J. Fussel, "Determination of the Pesticide Diflubenzuron in Mushrooms by High-Performance Liquid Chromatography-Atmospheric Pressure Chemical Ionisation Mass Spectrometry," Journal of Chromatography A, Vol. 712, No. 1, 1995, pp. 85-93. doi:10.1016/0021-9673(95)00481-2

[45] E. Rodriguez, R. J. Barrio, A. Goicolea, R. Peche, Z. Gómez de Balugera and C. Sampedro, "Presistance of the Insecticides Dimilin 45 ODC on Conifer Forest in an Atlantic Climate Ecosystem," Environmental Science Technology, Vol. 35, No. 18, 2001, pp. 3804-3808. doi:10.1021/es0106927

[46] S. A. Fischer and L. W. Hall, "Environmental Concentrations and Aquatic Toxicity Data on Diflubenzuron (Dimilin)," Critical Reviews in Toxicology, Vol. 22, No. 1,
1992, pp. 45-79. doi:10.3109/10408449209145321

[47] L. S. Mian and M. S. Mulla, "Biological and Environmental Dynamics of Insect Growth-Regulators (Igrs) as Used against Diptera of Public-Health Importance," Residue Reviews, Vol. 84, 1982, pp. 27-112. doi:10.1007/978-1-4612-5756-1_2

[48] K. A. Smith, A. A. Grigarick, J. H. Lynch and M. J. Oraze, "Effect of Alsystin and Diflubenzuron on the Rice Water Weevil (Coleoptera, curculionidae)," Journal of Economic Entomology, Vol. 78, No. 1, 1985, pp. 185189.

[49] G. W. Ivie, D. L. Bull and J. A. Veech, "Fate of Diflubenzuron in Water," Journal of Agricultural and Food chemistry, Vol. 28, No. 2, 1980, pp. 330-337. doi:10.1021/if60228a063

[50] C. Alzieu, "Toxicité et Persistance en Milieu Marin d'un Insecticide Dérivé des Benzoylurées: Le Diflubenzuron," Revue des Travaux de l'Institut des Pêches Maritimes, Vol. 41, No. 4, 1977, pp. 317-324. 